\title{
现代农业转型发展与食物安全供求趋势研究
}

\author{
黄季焜 $^{1}$, 王济民 ${ }^{2}$, 解伟 ${ }^{1}$, 王晓兵 ${ }^{1}$, 侯玲玲 ${ }^{1}$, 周慧 ${ }^{2}$, 盛誉 ${ }^{1}$, 刘旭 ${ }^{3}$ \\ (1. 北京大学中国农业政策研究中心，北京 100871；2. 中国农业科学院农业经济与发展研究所，北京 100081； \\ 3. 中国工程院, 北京 100088）
}

摘要: 在全球背景下厘清我国未来农业转型方向、生产方式转变路径和食物供求变动趋势, 提出现代农业转型发展战略和政 策建议。我国农业发展面临着六大挑战, 应深入推进农业供给侧结构性改革, 优化产品产业结构, 改善农产品供求结构, 提 升农产品质量安全水平。通过大样本农户调研数据分析发现, 应不断完善土地流转市场和社会化服务体系来保障现代农业转 型发展。面向 2035 年的农业生产结构调整预测表明, 我国农产品的供需失衡现象将趋向突出: 饲料自给率将继续下降, 食 糖和食油的需求缺口将逐渐扩大, 畜产品生产和供需缺口将取决于饲料粮贸易政策和草牧业发展政策, 但蔬菜和水果依然保 持一定的比较优势。

关键词: 农业生产结构; 食物安全; 供给; 需求

中图分类号: F32 文献标识码：A

\section{Modern Agricultural Transformation and Trend of Food Supply and Demand in China}

\author{
Huang Jikun ${ }^{1}$, Wang Jimin ${ }^{2}$, Xie Wei ${ }^{1}$, Wang Xiaobing ${ }^{1}$, Hou Lingling ${ }^{1}$, Zhou Hui ${ }^{2}$, \\ Sheng Yu ${ }^{1}$, Liu Xu ${ }^{3}$ \\ (1. China Center for Agricultural Policy, Peking University, Beijing 100871, China; 2. Institute of Agricultural Economics and \\ Development, Chinese Academy of Agricultural Sciences, Beijing 100081, China; 3. Chinese Academy of Engineering, \\ Beijing 100088, China)
}

\begin{abstract}
This study aims to clarify the direction for agricultural transformation, the transformation path of production, and the trend of food supply and demand in China, and to propose development strategies and policy suggestions for China's agriculture transformation. Facing six major challenges in agricultural development, China should further promote supply-side structural reform for its agriculture, optimize production structure, improve the supply and demand of agricultural products, and upgrade the quality of these products. After analyzing the panel data of farmer surveys, we propose to promote China's modern agricultural transformation by improving the land transfer market and the socialized service system. Our projection analyses indicate that the imbalance between supply and demand of many agricultural products in China will be prominent by 2035. China's feed self-sufficiency rate will continue to decline, and the demand gap for sugar and edible oil will gradually expand. The production of livestock products and the gap between supply and demand will largely depend on the feed grain trade policy and the grassland development policy, while vegetables and fruits still maintain a certain export comparative advantage.
\end{abstract}

Keywords: agricultural production structure; food security; supply; demand

收稿日期 : 2019-09-25; 修回日期 : 2019-10-08

通讯作者: 刘旭, 中国工程院院士, 主要研究方向为种质资源; E-mail: liuxu01@caas.cn 资助项目：中国工程院咨询项目 “国际化绿色化背景下国家区域食物安全可持续发展战略研究” (2016-ZD-09)

本刊网址 : www.engineering.org.cn/ch/journal/sscae 


\section{一、前言}

在国内外环境发生深刻变化的复杂形势下, 我 国农业发展面临诸多挑战。保障国家粮食安全和家 庭食物营养安全的任务艰巨，农业科技创新乏力制 约农业增长潜力, 小规模生产与农民增收及农业现 代化的矛盾日益突出。工资和耕地租金的上涨导致 我国农产品比较优势下降, 已经明显影响了我国农 产品的国际竞争力。短期内解决市场扭曲下的生产 结构与需求脱节、国内外农产品价格严重倒挂和国 内粮食等主要农产品库存加剧等问题任务艰巨; 长 期来看, 水资源短缺、耕地退化等生态恶化问题更 威胁着中国农业的可持续发展。

2019 年《中共中央、国务院关于坚持农业农村 优先发展做好 “三农” 工作的若干意见》要求：立 足国内保障粮食等重要农产品供给, 统筹用好国际 国内两个市场、两种资源, 健全保障体系。为了更 好适应农业发展新形势, 亟需回答一系列问题, 例 如, 在全球背景下, 农业生产结构如何根据中国食 物供求变动而调整? 如何发挥我国农产品比较优 势, 促进现代农业结构调整并保障食物安全? 如何 理清现代农业转型的方向与趋势, 提出可行的农业 生产方式转变的途径和发展战略? 本文梳理我国农 业的主要特征和未来农业发展面临的主要挑战, 从 发挥农产品比较优势和新型经营主体发展角度, 重 点探讨我国食物安全保障战略和现代农业转型发展 路径。

\section{二、全球农业发展背景}

\section{（一）农产品需求}

联合国预测，全球人口数量将从 2017 年的 75 亿增加到 2050 年的 97 亿, 增长幅度达 $28 \%$ [1]。 发展中国家随着收入增长和城市化进程推进, 居民 人均消费将不断增长, 对高附加值农产品（水产品、 畜产品、蔬菜等) 的消费也将出现显著增长。

\section{（二）耕地和水资源分布}

世界耕地和人口分布的差异，很大程度上影响 了农产品的生产结构和贸易, 人均耕地条件的差异 性导致了各地农产品结构的差异性。由于耕地和人 口分布不均匀, 农产品领域的贸易会对一些国家产
生非常重要的影响。未来全球耕地增长主要出现在 那些人少地多的国家, 而人多地少的国家耕地还可 能会下降, 这意味着耕地和人口的差异会进一步扩 大，也带来了农产品国际贸易的规模扩大。食物是 主要的贸易产品之一, 不管是人均耕地多的国家, 还是人多地少的国家, 人均进口粮食量都会继续 增长。

水资源分布情况比耕地更加严峻 [2]。一方面, 灌溉用水需求不断增长, 其他用水需求也在增长; 另一方面, 水的总供给量难以增加, 可用量可能还 会减少。到 2050 年, 全球水资源短缺的形势趋于 严峻, 我国北方地区尤为突出。有研究表明, 全球 生物安全最大的威胁来源不是土地资源短缺, 而是 水资源短缺 [3]。

\section{（三）粮食生产现状}

美国的耕地产粮率约为 $8 \mathrm{t} /\left(\mathrm{hm}^{2} \cdot \mathrm{a}\right)$, 世界上达 到这一水平的国家数量仅占全部国家数量的 $5 \%$, 对应粮食产量约占世界总产量的 $1 \%$ 。中国的耕地 产粮率接近 $6 \mathrm{t} /\left(\mathrm{hm}^{2} \cdot \mathrm{a}\right)$, 处于这一水平的国家数量 占全部国家数量的 $42 \%$, 对应粮食产量约占世界总 产量的 50\%。换言之, 世界约一半的粮食是由产粮 率低于 $5 \mathrm{t} /\left(\mathrm{hm}^{2} \cdot \mathrm{a}\right)$ 的国家生产的。由此可见, 世界 粮食生产还有很大增长潜力, 许多国家未来农业增 长将主要依赖于生产力的提高。保障中国食物安全, 应当更加关注发展中国家的粮食生产增长。

\section{（四）发达国家农业政策}

发达国家的农业政策已从过去 30 年的以市场 干预为主转向了目前的以市场化方式为主，从巨额 农业补贴转向了提高农业生产力、保障资源环境。 发达国家已经将增强竞争力和可持续发展作为未来 农业发展的政策导向。

\section{三、全球背景下我国农业发展面临的主要 挑战}

我国农业生产在面临发展机遇的同时也将面临 着一系列挑战, 包括食物自给与食品安全有所欠缺、 农产品比较优势不足、农业生产力增长乏力、农业 生产经营规模小、农产品市场保护机制僵化、自然 资源面临退化等。 


\section{（一）食物与食品安全}

我国食物总体供需难以平衡, 部分农产品供需 明显短缺。食物总体自给率和粮食自给率均呈不断 下降态势, 如果没有农业科技的重大突破, 2030 年 粮食自给率将不足 $85 \%$, 饲料玉米和大豆进口量将 分别达到 $4 \times 10^{7} \mathrm{t} 、 1 \times 10^{8} \mathrm{t}$, 食用油、糖和奶制品 等食品以及牧草等的进口也将显著增长 [4]。

我国人口营养不良现象不可忽视, 食品安全问 题较为严重。人口的营养不良和微量营养素缺乏现 象还较为普遍, 根据中国科学院地理科学与资源研 究所农业政策研究中心的调查, 贫困农村婴幼儿营 养良好状况整体不佳, 存在普遍的贫血现象, 小学 生贫血比例达 $33 \%$ 。不断出现的食品安全事件, 直 接影响着消费者对国内食品安全的信心。

\section{（二）劳动力工资上涨和农产品比较优势}

劳动力工资上涨是客观现象, 但一定程度上降 低了我国农产品的比较优势。近年来农业生产的劳 动力机会成本显著提高, 劳动力实际工资的年度增 速达到 $8 \%$ 。不采取有效的应对措施，如用机械替 代劳动力 [5], 将很大程度上影响我国农产品在国 际市场的比较优势和竞争力。例如, 国产玉米的比 较优势在 2007 年之后直线下降，在 2010 年后已经 体现为明显的比较劣势; 棉花和大豆在 2003 年后 呈现明显的比较劣势; 猪肉从 2006 年开始具有比 较优势, 2015 年后转变为比较劣势; 蔬菜、水果始 终保持比较优势, 但比较优势水平有所下降。

\section{（三）农业科技创新}

我国农业科技创新面临的挑战主要体现在农业 科研体系和基层农技推广体系两方面 [4]。农业科 研体系方面的突出问题有: (1)农业科研缺乏吸引 力; (2)农业科研立项与实际技术需求之间存在脱节 现象，难以满足农业生产对各种技术的需求; (3)农 业公共科研单位定位不清, 大型企业难以参与农业 科技创新； (4)农业科研投入依然不足，科研人员急 功近利现象明显, 难以积累形成重大研究成果。

基层农技推广体系方面的突出问题有：(1)基层 农业技术推广部门的职能定位还未完全理清; (2)基 层农技推广管理体制没有充分理顺; (3)技术推广人 员相关激励机制缺乏; (4)技术推广队伍建设薄弱,
推广能力偏低, 难以适应新技术扩散要求; (5)传统 的 “自顶到下” 的技术推广模式难以适应农业发展 需要, 对农民技术需求的信息缺乏反馈机制, 难以 满足农民增收的多元化需求; (6)农业技术推广投入 不足，基层农技推广部门难以发挥应有作用。

\section{（四）农户小规模生产}

小规模的农业生产经营方式与提高劳动生产 率、实现农业现代化之间的矛盾日益凸显。我国 当前的农作物生产体系主要由 2 亿多小农户组成, 户均耕地从 20 世纪 80 年代初的约 $0.8 \mathrm{hm}^{2}$ 下降到 2003 年的不足 $0.54 \mathrm{hm}^{2}$, 虽然之后户均耕地经营 规模有所上升, 但到 2016 年也仅约 $1.0 \mathrm{hm}^{2}$ 。如此 小的生产规模从根本上制约了农民的农业生产积极 性, 实现农民增收难度较大。此外, 小规模生产与 技术推广、机械化、信息化和食品安全的矛盾也日 益突出, 制约着农业现代化的进程。

\section{（五）农业支持政策}

我国许多农业支持政策难以达到预期效果，主 要体现为：(1)农业补贴政策财政成本高、增收效果 趋于弱化, 对农业生产力和可持续发展的积极影响 不明显 [6]; (2)农产品购销和价格干预政策不但没 有降低生产成本，反而扭曲市场机制、影响资源合 理配置, 使农业生产结构严重失衡; 而取消价格干 预政策又将对农民收入产生负面影响；(3)关税制度 对避免中国农产品受国际市场冲击的作用有限, 中 国农产品的平均关税水平（约 15\%) 远低于世界农 产品的平均关税水平 (约 $62 \%$ ), 贸易保护措施的 选择和发挥空间很小; 采用有争议的非贸易壁垒的 措施也只能在短期内产生极其有限的影响（而这常 常会引起贸易争端)。

\section{（六）农业资源环境}

我国农业生产面临日益严峻的水资源短缺和耕 地退化的威胁。中国作为人多地少的大国，是世界 上水资源最短缺的国家之一。随着工业化和城市化 的持续推进，仅仅是维持目前的耕地数量和质量就 需要付出巨大努力。水土资源的质量恶化同时还威 胁着食物安全, 气候变化也给农业生产带来诸多极 不确定的影响和风险。 


\section{四、农产品比较优势与农业结构调整}

\section{（一）产品方面}

稳定稻谷和小麦生产, 事关我国口粮绝对安全 和国家粮食安全的大局。应当优化品种结构, 提高 产品质量, 降低生产成本, 提升产品竞争力, 缓解 进口冲击压力。

进一步提高蔬菜和果业的比较优势, 在保障出 口质量的同时，依靠科技进步和生产经营管理水平 提升, 来降低生产成本、保持出口价格优势、扩大 国际市场占有率。

提高养殖业的比较优势, 充分利用我国养殖业 以及居民生鲜产品消费偏好的优势, 提高产品质量, 取得与发达国家的竞争优势。

发展具有比较优势、资本投入密集的农产品, 加大政策扶持力度, 引导产业资本增加投入, 扩大 生产份额, 增强国际市场竞争力, 由此弥补我国传 统劳动密集型农产品的相对优势削弱或消失所带来 的竞争力缺口。

\section{（二）政策方面}

将财政支农的重点逐渐从农业补贴、农产品购 销和市场干预等, 转向有助于提升生产力、降低生 产成本的投入, 加大支持优质、高效农产品和优势 特色产业的发展力度, 从而保障农产品质量安全。

完善农民收入稳定增长支持政策。扶持高效养 殖业和乡村休闲旅游业发展, 推动一产、二产、三 产的融合发展来拓展农业产业链和价值链, 促进农 民就业和收入的增长; 支持发展适度规模经营, 提 高规模化效益; 完善农业保险政策, 提高农民抗御 自然灾害风险和市场风险的能力。

完善绿色发展支持政策。坚持以绿色生态可持 续为导向, 实施化肥农药减量行动; 促进农作物秸 秆和畜禽粪便的多样化处理; 鼓励发展节水农业; 倡导耕地、草原的生态保护, 对按计划休耕轮作和 退牧还草的农户给予相应补贴。

\section{（三）目标效果}

保障国家粮食安全和主要农产品有效供给, 优 化产品产业结构, 保持农民收入稳定增长, 实现生 产生态协调发展, 增强农业内在发展动力, 提高农 业生产力水平, 促进农村全面发展。具体目标为:
（1）稳步提升农业综合生产能力，确保谷物基 本自给、口粮绝对安全, 提升畜产品生产力和竞争 力, 保障国家口粮和畜产品安全。

（2）深入推进农业供给侧结构性改革，优化产 品产业结构, 改善农产品供求结构, 提升农产品质 量安全水平。

（3）推行绿色生产方式, 落实农药化肥零增长 计划, 大力提高水资源利用效率, 有效治理农村环 境突出问题, 实现生产生态协调发展。

（4）坚持以市场为导向, 完善主要农产品价格 形成机制和价格调节机制, 增强农业内在发展动力。

\section{五、从新型经营主体发展视角探讨现代农业 转型发展路径}

\section{（一）新型经营主体发展趋势}

根据面向东北和华北地区的调查数据, 大户 (或家庭农场)、土地合作社和农业企业等新型经营 主体的数量增长迅速。特别是 2008 年以来, 土地 合作社和经营农地的农业公司开始独立于家庭农 户，成为新的生产经营主体 (见表 1)。这些新的生 产经营主体（经营土地面积大于 $7 \mathrm{hm}^{2}$ ), 尽管占生 产者总数的比例仅约 $1 \%$, 但其所占耕地的比例在 2013 年达到 $27 \%$ 、在 2016 年超过 $35 \%$ 。

\section{（二）新型经营主体发展的影响因素}

对东北和华北的实证研究表明, 近年来新型经 营主体的快速发展、耕地经营规模的显著提升, 主 要得益于三大市场驱动力和两大政策因素。

1. 市场驱动力因素

一是劳动工资的快速增长。2 008 年以来, 非农 就业工资（或农业生产机会成本）和农业生产雇工 工资都以年均 $8 \%$ 左右的速度增长。劳动成本上升 促进了城乡移民的流转, 提高了使用劳动密集型生 产技术的家庭农户的生产成本, 从而加快了耕地流 转和土地整合。

二是农地市场的发育和完善。虽然近几年有不 少地方建立的土地流转平台名不符实, 但在更早的 前几年, 一些地方发展起来的土地流转平台成为土 地流转市场上的重要制度创新, 明显降低了农地流 转的交易成本和风险, 在促进土地流转和规模经营 方面起到积极的推动作用。例如, 在东北和华北地 
表 1 不同经营规模的经营主体的比例及其平均经营规模

\begin{tabular}{|c|c|c|c|c|c|c|c|c|}
\hline & \multicolumn{4}{|c|}{ 不同经营规模的经营主体比例 $/ \%$} & \multicolumn{4}{|c|}{ 平均经营规模 $/ \mathrm{hm}^{2}$} \\
\hline & 2003 & 2008 & 2013 & 2016 & 2003 & 2008 & 2013 & 2016 \\
\hline 土地合作社 & 0 & 0.0005 & 0.14 & 0.2 & - & 55.0 & 216.0 & 339.0 \\
\hline a) 仅支付租金型 & 0 & 0 & 0.01 & 0.05 & - & - & 109.0 & - \\
\hline b) 仅利润分红型 & 0 & 0.0005 & 0.12 & 0.15 & - & 67.0 & 138.0 & - \\
\hline c) 既支付租金又利润分红 & 0 & 0 & 0.01 & 0 & - & - & 128.0 & - \\
\hline 公司 & 0 & 0.0002 & 0.01 & - & - & 43.0 & 500.0 & 400.0 \\
\hline 农户 & 100 & 99.999 & 99.85 & 99.75 & 1.7 & 2.2 & 4.5 & 5.0 \\
\hline$<1 \mathrm{hm}^{2}$ & 73.4 & 68.5 & 59.5 & 53.9 & 0.5 & 0.5 & 0.5 & 0.5 \\
\hline $1 \sim 2 \mathrm{hm}^{2}$ & 15.7 & 17.2 & 18.8 & 21.2 & 1.4 & 1.4 & 1.4 & 1.5 \\
\hline $2 \sim 3 \mathrm{hm}^{2}$ & 6.6 & 8.6 & 12.7 & 13.7 & 2.4 & 2.4 & 2.3 & 2.5 \\
\hline $3 \sim 7 \mathrm{hm}^{2}$ & 4.1 & 5.4 & 8.1 & 9.6 & 4.4 & 4.6 & 4.4 & 5.0 \\
\hline $7 \sim 15 \mathrm{hm}^{2}$ & 0.2 & 0.2 & 0.5 & 1.1 & 9.7 & 9.7 & 9.9 & 10.1 \\
\hline$>15 \mathrm{hm}^{2}$ & 0 & 0 & 0.2 & 0.3 & 24.2 & 33.0 & 50.6 & 31.1 \\
\hline
\end{tabular}

注：2003、2008、2013 年数据为 6 省样本, 分别为黑龙江、吉林、辽宁、山东、河北、河南; 2016 年数据为 4 省样本, 分别为黑龙江、吉林、山东、河南。所 有的数据均为加权计算。数据来源于作者调研数据。

区, 2003 年租入和租出土地的农户比为 $1: 1.3$, 这 一比例在 2013 年为 $1: 3$ 、在 2016 年达到 $1: 4$ 。

三是以市场为导向的农业机械社会服务体系的 快速发展。农村资本市场的开放和各地迅速发展起 来的有偿社会化服务, 为农户扩大经营规模提供了 必要的机械设备条件。农业机械社会服务体系的发 展，有助于广大农户克服扩大耕地经营规模所受到 的投资约束的困难, 这种发展对农户经营规模的综 合影响为正面。

\section{2. 政策因素}

一是粮食等农产品的目标价格和收储政策。水 稻和小麦粮食最低收购价、玉米和其他农产品的临 时收储政策维持了粮食及主要农产品的销售价格, 降低了农产品的市场风险, 吸引了不少农业企业、 个体或新的生产者投入到农业生产行业。在一些地 方新增生产者已成为农业生产的重要经营主体。

二是针对耕地经营大户、合作社和企业等新 型主体进行补占的扶持政策。许多地方政府培育 新型农业经营主体, 主要目标是扩大耕地经营规 模, 甚至将农业规模化视为农业现代化来予以推进。 2008 年以来, 许多地方对新型主体实施了各种补贴 和优惠政策政策, 获得政策支持的最低耕地经营规 模因地而异，从不小于 100 亩 (1 亩 $\approx 666.667 \mathrm{~m}^{2}$ ) 到超过 250 亩不等。这些支持性政策大力推动了新 型经营主体的发展, 促进了农地经营规模的扩大化。

\section{（三）新型经营主体发展面临的问题}

\section{1. 超过适度规模水平}

耕地经营规模与粮食单产呈倒 U 型关系, 平均 转折点不到 100 亩。这个转折点因各村庄的耕地规 模、地块平整与连片程度、不同粮食作物、田间管 理水平、社会化服务发展等变化而变化。在现有的 生产环境、技术、管理和市场条件下，不同地方的 适度经营规模分布在 40 200 亩范围。

耕地经营规模与粮食成本 (元 $/ \mathrm{kg}$ ) 呈 U 型关系, 平均转折点在 100 亩左右, 略高于单产的平均转折 点。和单产相似, 适度经营规模的转折点也因地因 时而异。

\section{2. 面临多种挑战}

2008-2013 年, 即使在粮食价格年年攀升情况 下, 多数规模偏大的新型主体只有在考虑政府补贴 后才有盈余。2016 年粮价下跌, 这些新型经营主体 多数出现了大幅度亏损的情况, 面临着生产经营“进 退两难” 的局面。如果粮价继续下跌, 这类主体直 接面临倒闭风险。

\section{3. 补贴问题较为突出}

补贴等扶持政策提高了农业劳动生产力价格, 但扭曲了土地市场、助长了低效的新型经营主体的 产生。这不但降低了粮食生产力和市场竞争力, 而 且也降低了全国农业增加值, 对广大农民增收和社 会就业也产生负面影响。 
4. 受资金、技术和人才等多种因素制约

不少地方新型经营主体成立的自身条件不成 熟。调查中, 近一半的县级农业主管领导和近 $1 / 3$ 的乡镇干部认为, 资金、技术和人才是目前制约新 型农业经营主体发展的主要因素。这从侧面反映了 规模经营的发展是有条件的, 超适度规模主体发展 会面临更多挑战。

\section{5. 缺乏监管和政策影响评估}

调查显示, 新型农业生产经营主体缺乏监管、 套取国家补占的现象较为普遍, 部分新型生产经营 主体更是名不符实, 还有一些种植大户为了套取补 贴而虚报耕地面积。调研的所有地方都没有对扶持 政策的效果开展过评估工作。

\section{6. 附带社会问题}

受外出打工能力制约和自己家庭食物需求 (如 蔬菜等) 的影响, 许多中年妇女、中老年男性劳动 力主要从事小规模农业生产。但个别地方因为全村 土地集中流转给企业或大户，原来务农的这些中老 年劳动力往往失业在家, 在目前农村文化生活还不 是很丰富的情况下, 可能产生新的社会问题。

\section{（四）新型经营主体发展的政策建议}

\section{1. 分类实施发展政策}

建议新型农业经营主体按农产品的生产特性分 类为: 大田农作物生产、非大田农作物生产（如蔬 菜与花卉设施农业和果园等)、养殖业 (如畜牧业 和水产业等)。

分类实施相应政策, 重点关注大田农作物生产 的适度经营规模和扶持政策; 创造良好的市场环 境, 让市场自主确定 “非大田农作物” 和养殖业的 适度规模。

2. 以大户为主发展合作经营模式

目前在许多地方，培育新型农业经营主体的 主要目标是扩大生产规模, 而对单位产品生产成本 (元 $/ \mathrm{kg}$, 即农业竞争力)、广大农民增收和农业可 持续发展的关注不够, 可能适得其反。

政策目标方面, 以提高全要素生产率和农产品 竞争力（降低单位产品生产成本）和广大农民的增 收为政策扶持目标。

政策措施方面, 对适度经营规模的生产主体, 特别是农户，实施扶持政策; 适度规模扶持政策要 因地制宜、动态调整, 对超过适度规模的经营主体
停止国家扶持政策。

\section{3. 完善土地流转市场和社会化服务体系}

让市场成为资源配置的主要决定因素, 通过制 度创新降低农地流转的市场交易成本和风险, 通过 政策扶持（如财政、信贷、技术和市场等服务）促 进适度经营规模生产主体的发展, 提高其在农业生 产中的比例。

要和城镇化实际进程同步发展, 稳妥推进规模 化经营。如果全国农地平均经营规模达到 100 亩, 只需要 $1.8 \times 10^{7}$ 个家庭农场; 如果平均规模达到 250 亩, 只需 $7.2 \times 10^{6}$ 个家庭农场。数以亿计的农民 就业是一个必须高度重视的社会问题, 推进新型农 业经营主体和规模经营是个长期的发展过程。

\section{六、农业结构调整和食物安全的目标预测}

针对基准方案开展我国未来主要农产品供需变 动趋势预测, 进而分析未来主要政策方案对农产品 供需影响。

\section{（一）基准方案宏观经济与社会指标设定}

为了分析中长期 (到 2035 年) 我国不同农产 品供需变化, 对经济增长、城市化率、未来工资增 长率、城乡收入价格弹性和不同产品的技术进步等 因素合理进行了一系列假设和判断。

在国内生产总值（GDP）增长率方面, 到 2020 年，年均 GDP 增长 $6 \%$ 7\% ; 2021-2025 年，年均 GDP 增长 5\% 6\%；2026-2030 年，年均 GDP 增长 $4 \% \sim 5 \%$; 在 $2031-2035$ 年间, 年均 GDP 增长保持 在 $4 \%$ 以上。

未来农村和城镇居民之间的收入差距会逐渐减 小，近期的变化趋势表明农村居民收入增长快于城 市居民。为此，假设农村居民人均可支配收入：到 2025 年, 年均实际增长 $6.2 \% ; 2026-2035$ 年, 年 均实际增长 $5.3 \%$ 。假设城镇居民人均可支配收入: 到 2025 年, 年均实际增长 5.6\%; 2026-2035 年, 年均实际增长 $4.8 \%$ 。

根据《国家人口发展规划（2016-2030 年)》, 我国总人口将在 2030 年前后达到峰值。为此, 预 计到 2020 年, 年均人口增长率为 $0.65 \%$, 人口达到 14.2 亿; $2021-2025$ 年, 年均人口增长率为 $0.21 \%$; 2026-2030 年，年均人口增长率为 $0.10 \%$, 到 2030 
年人口达到 14.5 亿; $2031-2035$ 年, 人口总量略微 下降, 维持在 14 亿 14.5 亿的水平。

中国的城镇化率不断提高, 预计到 2020 年, 城镇化率年均提高 $1.4 \%$, 城镇化率达到 $60 \%$; $2021-2025$ 年, 城镇化率年均提高 $1.5 \%$, 到 2025 年达到 64\%；2025-2030 年城镇化率年均提高 $1.6 \%$, 到 2030 年达到 70\%；2031-2035 年城镇化 率年均提高 $1.7 \%$ ，到 2035 年达到 $75 \%$ 。

农业科技研发方面，国家将继续加大农业科技 投入, 但是随着单产提高的边际成本增加, 科技水 平的贡献率有下降趋势。

全球粮食价格方面, 国际农产品在 2025 年前 的价格主要参考美国农业部 (USDA) 和经济合作 与发展组织 - 粮食及农业组织 (OECD-FAO) 的农 业展望结果, 预计到 2026-2035 年国际农产品价 格将保持平稳。

\section{（二）基准方案下农产品供需变动趋势预测}

到 2025 年和 2035 年, 主要农产品的需求量和 产量预测结果分别见图 1 和图 2。整体来看, 未来 我国多类农产品的供需失衡现象将更为突出, 这种
局面将延续到 2035 年前后。

我国饲料需求增长将显著高于国内生产增长, 自给率将不断下降。在现有国内农业生产资源、政 策、技术进步和需求变化条件下，到 2035 年，大 米和小麦等口粮基本可以自给；尽管玉米之前受政 策干预影响而出现供过于求, 但随着畜产品需求增 长, 对玉米饲料的需求将显著增长, 如果不采用关 税配额制管理, 2035 年玉米进口将超过 $5.6 \times 10^{7} \mathrm{t}$, 玉米自给率将下降到 $82 \%$; 大豆供需缺口也将进一 步加大。

我国食糖和食油的需求将显著高于国内生产, 供需缺口将逐渐扩大。根据预测, 到 2035 年, 食 糖自给率将降低到 $40 \%$, 油料作物自给率将保持在 $87 \%$ 左右。

我国棉花生产将逐渐萎缩, 棉花供需缺口进一 步扩大。在维持新疆棉花生产量的情况下，2035 年 棉花自给率将降低到 67\%。值得注意的是, 棉花生 产挤占了新疆等地有限的水土资源。

蔬菜和水果 (包括瓜果) 产量将稳定增长, 而 且将依然保持一定的出口比较优势。我国是世界上 最主要的蔬菜和水果出口国之一，未来将继续保持

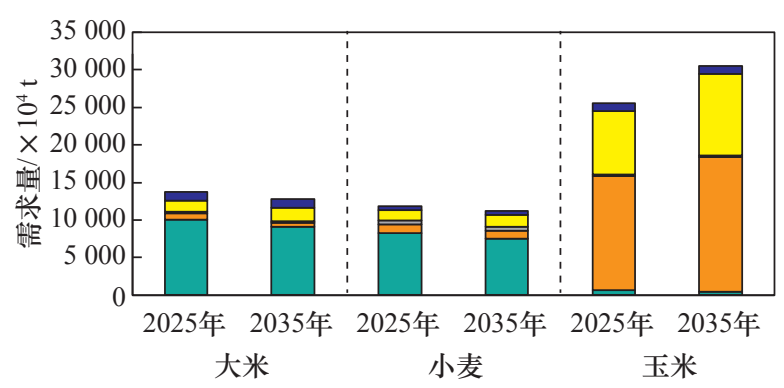

口居民消费; 口饲料粮需求; 口种子需求; 口工业需求; 口产后损失 （a）大米、小麦、玉米需求量预测

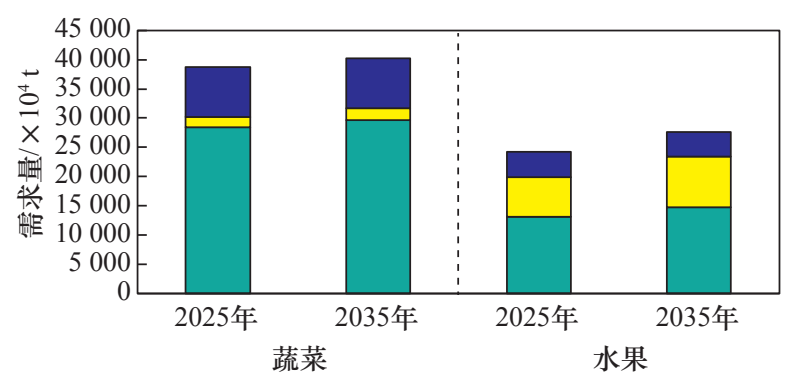

口居民消费; 口饲料粮需求; 口种子需求; 口工业需求; 口产后损失

(c) 蔬菜、水果需求量预测

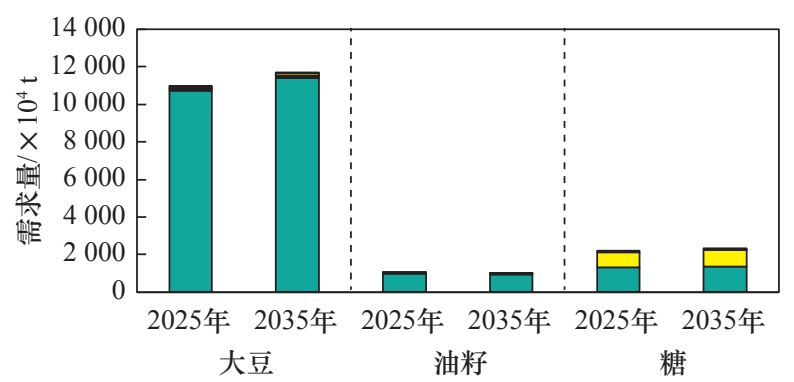

口居民消费; 口饲料粮需求; 口种子需求; 口工业需求；口产后损失 (b) 大豆、油籽、糖需求量预测

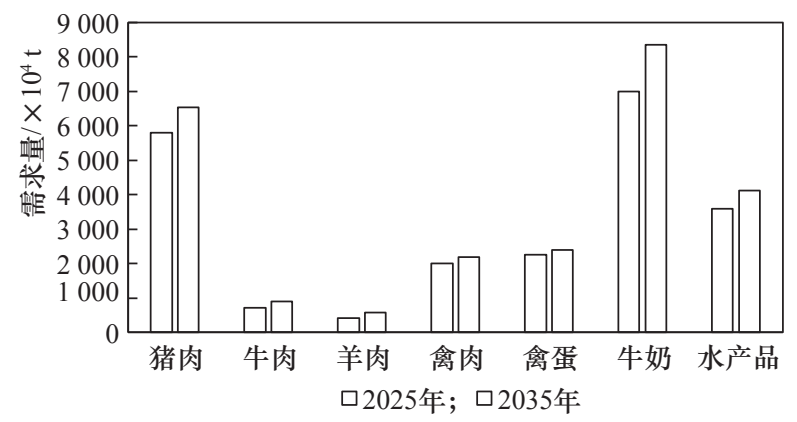

（d）肉、蛋、奶及水产品需求量预测

图 12025 年和 2035 年主要农产品需求量预测 


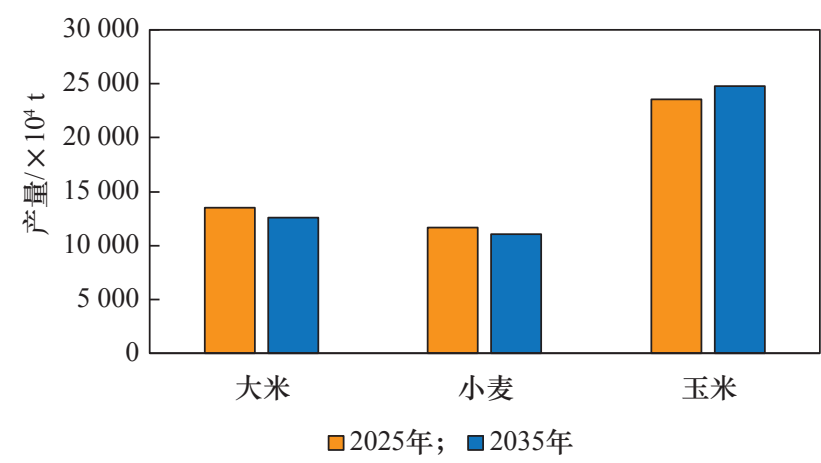

（a）大米、小麦、玉米产量预测

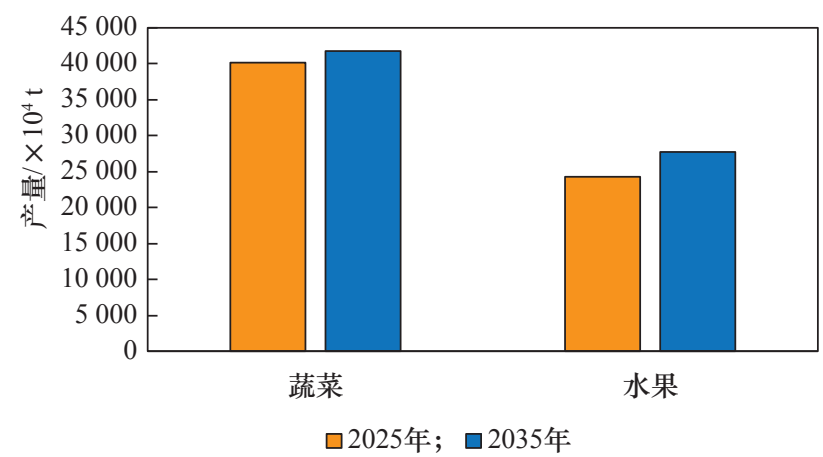

(c) 蔬菜、水果产量预测

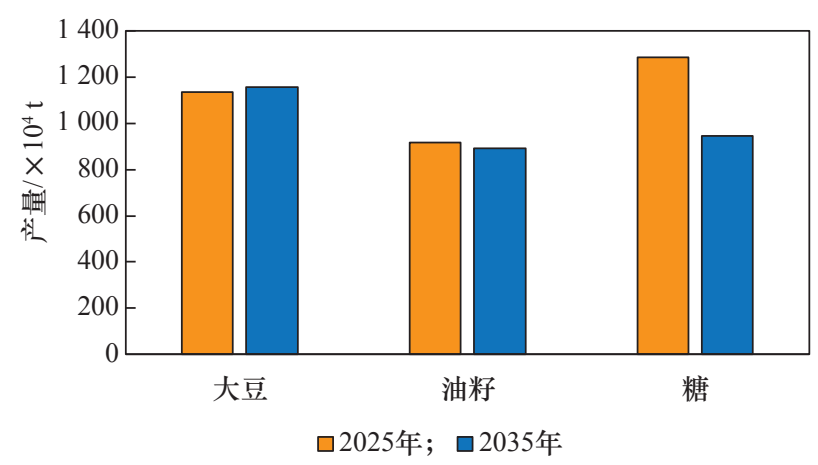

(b) 大豆、油粕、糖产量预测

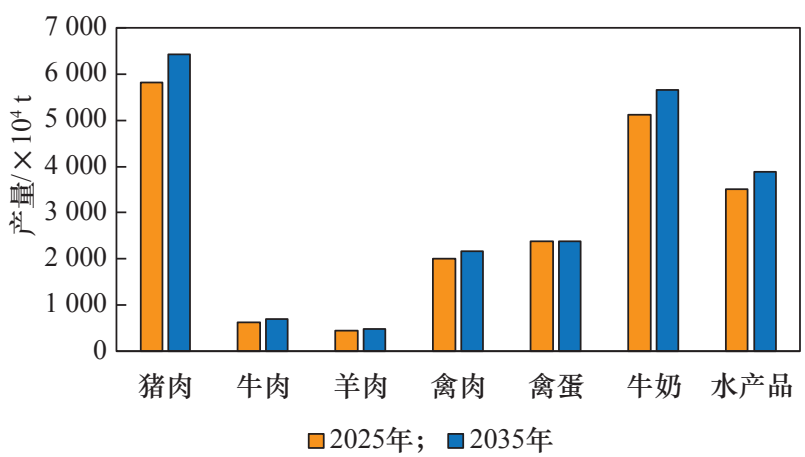

（d）肉、蛋、奶及水产品产量预测

图 22025 年和 2035 年主要农产品产量预测

较弱的比较优势。到 2035 年, 蔬菜自给率将保持 在 $104 \%$ 左右，水果自给率将保持在 $100 \%$ 左右。

在养殖业部门，除了水产品外，许多畜产品的 生产和供需缺口将很大程度上取决于饲料粮贸易 政策和草牧业发展政策。根据预测, 到 2035 年, 水产品供需基本平衡、略有进口, 但畜产品供需 平衡存在不确定性。为了保障我国未来的食物安 全 (主要为畜产品的供给安全), 是增加畜产品进 口, 还是增加饲料粮进口, 需要有明确战略和稳 定政策。如果放开饲料粮市场、通过进口饲料发 展国内畜牧业, 除了牛羊肉和奶制品以外, 其它 畜产品供需基本保持平衡。但在限制玉米进口、 不重视草牧业发展的情况下, 中国畜产品进口将 显著增长, 且高度依赖于不可靠的国际市场供给。 除了进口猪肉和命肉外, 牛羊肉和奶制品进口增 速将更为显著, 到 2035 年, 这些产品的自给率将 下降到 70\% 80\%。

\section{七、结语}

我国农业已经进入了新时代, 农业发展需要新
的顶层战略、新的发展思路。过去 40 多年我国农 业增长是以牺牲环境和可持续发展为代价的, 原有 的农业生产方式已不能适应未来保障食物安全和农 业可持续发展的要求。

立足全球农业发展背景, 梳理我国农业发展具 体面临的挑战, 从产品、政策和目标方面指出了农 业结构调整方向。结合大样本数据调查和数据分析, 完成现代农业转型发展的评价研究, 科学预测了未 来我国农业生产结构调整目标, 探讨分析了现代农 业生产方式的转变路径。在此基础上提出现代农业 转型的战略目标、战略重点和政策建议, 以期为我 国农业发展的学术和政策研究提供参考借鉴。

\section{参考文献}

[1] 联合国经济和社会事务部人口司. 世界人口展望2019 [R]. 纽 约: 联合国经济和社会事务部人口司, 2019.

Population Division, Department of Economic and Social Affairs, United Nations. World population prospects 2019 [R]. New York: Population Division, Department of Economic and Social Affairs, United Nations, 2019.

[2] Grafton R Q, Williams J, Jiang Q. Food and water gaps to 2050: Preliminary results from the global food and water system (GFWS) platform [J]. Food Security, 2015 (7): 209-220. 
[3] Rosegrant W M, Cai X, Cline S A. Global water outlook to 2025: Averting an impending crisis [J]. New England Journal of Public Policy, 2007, 21(2): 102-127.

[4] 黄季焜. 新时期的中国农业发展: 机遇、挑战和战略选择 [J]. 中 国科学院院刊, 2013 (28): 295-300.

Huang J K. China's agricultural development in the new era: Opportunities, challenges, and strategies [J]. Bulletin of Chinese Academy of Sciences, 2013 (28): 295-300.

[5] Wang X B, Yamauchi F, Otsuka K, et al. Wage growth, land- holding, and mechanization in Chinese agriculture [J]. World Development, 2016, 86(5): 30-45.

[6] 黄季焜, 王晓兵, 智华勇, 等. 粮食直补和农资综合补贴对农业 生产的影响 [J]. 农业技术经济, 2011 (1): 4-12.

Huang J K, Wang X B, Zhi H Y, et al. Effects of direct subsidies for grain and comprehensive subsidies for agricultural materials on agricultural production [J]. Journal of Agrotechnical Economics, 2011 (1): 4-12. 